\title{
Aplikasi Sistem Pertanian Organik Pada Budidaya Tanaman Sawi Umur Genjah di Kawasan Taman Udayana
}

\author{
Wahyu Astiko", Agus Rohyadi , Mery Windarningsih, Irwan Muthahanas \\ Program Studi Agroekoteknologi, Fakultas Pertanian Universitas Mataram \\ Jalan Majapahit No. 62 Mataram, Lombok, Indonesia, 83125
}

\begin{abstract}
Kata Kunci:
Abstrak: Tujuan kegiatan pengabdian masyarakat ini adalah (1) Menjelaskan pertanian kepada petani tentang kelebihan dan keuntungan praktik sistem pertanian organik, organik, khususnya diawali dengan penggunaan pupuk hayati mikoriza dan bahan organik untuk mengurangi dan mengganti penggunaan pemberian pupuk kimia sintetik. (2) Mendemontrasikan praktik sistem pertanian organik kepada petani tanaman sawi sehingga penggunaan pupuk kimia maupun pestisida kimia yang selama ini diberikan berlebih dapat dikurangi secara bertahap. Metode pelaksanaan kegiatan yang diterapkan dalam kegiatan pengabdian masyarakat ini meliputi: (1) Pertemuan diskusi dan penyuluhan, (2) Demoplot dan praktik lapang, (2) Evaluasi keberhasilan program. Berdasarkan hasil kegiatan pengabdian masyarakat ini dapat diketahui (1) Petani tanaman sawi di Muncuk dapat mengetahui dan memahami secara langsung beberapa kelebihan dan keuntungan dari praktik aplikasi sistem pertanian organik, khususnya diawali dengan penggunaan pupuk hayati mikoriza dan pemberian pupuk organik untuk mengurangi dan mengganti penggunaan pupuk kimia sintetik. (2) Praktik aplikasi sistem pertanian organik pada usaha tani tanaman sawi dapat mengurangi penggunaan pupuk kimia maupun pestisida kimia secara bertahap.
\end{abstract}

Korespondensi: astiko@unram.ac.id

\section{PENDAHULUAN}

Kawasan Udayana Rembiga merupakan suatu kawasan di Kecamatan Selaparang yang lokasinya sangat strategis untuk budidaya sayuran organik. Kelurahan Rembiga merupakan salah satu kelurahan yang ada di Kota Mataram yang terletak pada posisi geograsfis: $116^{\circ} 04^{\prime}-116^{\circ} 10^{\prime}$ Bujur Timur dan $08^{\circ} 33^{\prime}-08^{\circ} 38^{\prime}$ Lintang Selatan. Tidak jauh dari Kelurahan Rembiga ini terdapat Taman Udayana yang terletak ditengah-tengah pusat kota Mataram. Taman ini merupakan taman yang memiliki banyak fungsi dalam dinamika kehidupan masyarakat kota Mataram maupun yang berasal dari luar Mataram. Taman ini juga menjadikan kawasan tempat yang paling nyaman untuk dikunjungi masyarakat, para pengunjung biasanya memilih lokasi ini untuk rekreasi atau sekedar berkumpul bersama teman sambil menikmati hidangan yang disuguhkan oleh warung-warung yang ada di sepanjang jalan ini. Pada waktu sore hari hingga tengah malam taman wisata ini ramai dikunjungi oleh berbagai kalangan. Beragam aktifitas di taman wisata ini, mulai dari yang hanya sekedar ngobrol, makan malam bersama keluarganya, hingga bertemunya berbagai macam komunitas yang sengaja berkumpul untuk silaturahmi antarsesama anggotanya.

Pada hari minggu pagi, pemerintah kota Mataram memperlakukan kawasan taman udayana ini sebagai arena bebas kendaraan bermotor (car free day), sehingga masyarakat dapat secara luluasa bererkreasi, berolahraga dan berbelanja aneka sayuran. Banyak produk sayuran dijual dipinggir jalan dalam keadaan segar. Namun banyak sayuran yang dijual cepat 
mengalami pembusukan apabila tidak segera terjual dan tidak dibudidayakan secara organik. Hal ini menimbulkan kekhawatiran adanya residu kimia pada produk sayuran yang dapat mempunyai efek merugikan terhadap kesehatan. Saat ini berkembang dibanyak kalangan untuk mengkonsumsi produk pertanian organik, non kimiawi dan mempunyai khasiat terhadap kesehatan.

Oleh karena itu untuk mengatasi permasalahan ini, upaya peningkatan produksi tanaman sayuran organik yang ramah lingkungan dan bebas residu pestisida mutlak perlu dilakukan. Salah satunya adalah dengan menggunakan pupuk organik yang berkualitas dan pemanfaatan pupuk hayati mikoriza (Astiko, 2015). Namun demikian banyak masalah yang ditemukan di lapangan, misalnya masih belum termanfaatkannya sumberdaya lokal, baik sumberdaya alam maupun iptek secara optimal.

Trend kebanyak masyarakat saat ini yang kembali ke kehidupan alam (back to nature) memerlukan perubahan pola pikir (main set) yang tidak selalu "kimia mainded" Perubahan pola pikir ini perlu juga ditularkan kepada kelompok-kelompok tani yang ada di pedesaan. Dalam pelaksanaan Pengabdian Pada Masyarakat (PPM) ini melibatkan kelompok tani yang ada di Kelurahan Rembiga Kecamatan Selaparang Kota Mataram, yaitu Kelompok Tani Terpadu "Karya Usaha Bersama" atau disebut juga Gabungan Kelompok Tani Terpadu (Gapoktan) "Karya Usaha Bersama" bergerak dibidang budidaya tanaman sayuran yang akan dilatih dalam pemanfaatan pupuk organik dan pupuk hayati mikoriza pada sistim budidaya sayuran organik berumur pendek.

Kegiatan UKM mitra adalah membudidayakan tanaman sayuran, namun teknologi yang diterapkan masih konvensional yang menuntut energi tinggi yang berupa pupuk dan pestisida. Ditinjau dari segi ekonomi, teknologi tersebut membutuhkan biaya yang tinggi, sedangkan di pihak lain tingkat permodalan petani adalah sangat rendah. Selain itu penggunaan pupuk buatan dan pestisida yang kurang bijaksana yang biasa diterapkan petani setempat per satuan luas cenderung selalu meningkat (Balitbang Pertanian, 2007). Hal ini ternyata mempunyai dampak negatif terhadap lingkungan. Demikian pula penggunaan pestisida yang semakin bertambah, selain merupakan pemborosan juga dapat mengganggu keseimbangan lingkungan seperti matinya musuh-musuh alami dan jasad bukan sasaran lainnya, resurgensi dan resistensi hama dan patogen, juga menyebabkan pencemaran lingkungan karena adanya residu pestisida di dalam tanah, air, tanaman dan kemungkinan dalam tubuh manusia. Berdasarkan situasi tersebut, maka perlu konsep baru dalam budidaya tanaman sayuran umur genjah yang tidak hanya berlandaskan ekonomi, tetapi juga perlu berwawasan lingkungan sehingga tercipta pola pertanian berkelanjutan (Astiko, 2014).

\section{METODE KEGIATAN}

\section{Penentuan lokasi dan target peserta}

Kegiatan pengabdian kepada masyarakat ini dilaksanakan di Dusun Muncuk Kelurahan Rembiga Mataram yang merupakan kawasan penghasil tanaman sawi yang letaknya berdekatan dengan Taman Udayana. Peserta kegiatan ini adalah anggota Gapoktan "Karya Usaha Bersama" dan masyarakat yang ada di sekitar lokasi pengabdian yang bekerja sebagai petani sayuran yang berdomisili di desa setempat, memiliki lahan garapan tanaman 
sawi, bersedia mengikuti petunjuk dan bimbingan dari penyelenggara kegiatan dan mau menyebarluaskan ilmu yang diperoleh kepada petani lainnya disekitar lokasi kegiatan.

\section{Metode Kegiatan}

Kegiatan ini dilaksanakan dengan metode pelatihan yang dilanjutkan dengan kerja praktek di lapangan atau melakukan demonstrasi dan kaji tindak partisipatif aktif (active partisipatory action research) di lapangan secara aktif sejak persiapan sampai selesai. Tahap kegiatan ini meliputi:

\section{a. Pelatihan budidaya sawi dengan pupuk hayati mikoriza}

Pelatihan dilakukan dengan memberikan materi tentang budidaya tanaman sawi yang ramah lingkungan dengan aplikasi pupuk hayati mikoriza dengan penambahan bahan organik sehingga diperoleh produk sawi organik yang mempunyai nilai jual tinggi.

\section{b. Demplot budidaya sawi umur genjag dengan aplikasi pupuk mikoriza dan bahan organik}

\section{b1. Praktek pembuatan pupuk hayati mikoriza}

Pupuk kandang sapi steril, tanah inokulum mikoriza, sekam padi, dedak, kapur, air gula dan EM4 dicampur hingga merata. Capmpuran selain air gula dan cairan EM4 dicampur hingga rata, kemudian siram dengan menggunakan gembor larutan campuran 5 sendok makan EM4 dan empat sendok gula pasir yang telah dilarutkan dalam satu ember air. Pemberian larutan dihentikan jika campuran pupuk kandang tersebut dikepal dengan tangan tidak ada air yang menetes. Tumpukan campuran ini kemudian ditutup dengan terpal dan dipertahankan jangan sampai suhunya melampaui suhu $45^{\circ} \mathrm{C}$, jika melebihi buka terpal kemudian aduk campuran hingga rata. Fermentasi campuran dilakukan selama 7 hari, jika campuran sudah berwarna gelap dan tidak berbau, maka campuran pupuk ini sudah jadi. Campuran ini lalu dikering-udarakan dibawah sinar matahari sampa kadar airnya mencapai 10-15\%. Campuran formulasi ini kemudian diayak untuk memisahkan kotoran dan batu kerikil yang ada. Hasil ayakan yang telah bersih, halus dan berbentuk tepung, kemudian ditimbang, lalu dimasukkan ke dalam kantong plastik kemasan $10 \mathrm{~kg}$ yang lebih dahulu telah diberi label produk.

\section{b2. Budidaya organik tanaman sawi dengan memanfaatkan mikoriza}

1) Persiapan Bibit

Benih sawi yang digunakan adalah jenis Sinta yang biasa di dibudidayakan oleh petani sawi yang banyak disukai konsumen.

2) Persiapan Lahan

Lahan yang akan digunakan dalam pengabdian ini $\pm 400 \mathrm{~m}^{2}$. Pengolahan tanah dilakukan dengan cara pencangkulan sebanyak dua kali. Pada pencangkulan pertama bongkahan tanah dibiarkan terangin-angin selama 2 hari, sedangkan ada pencangkulan ke dua dilakukan bersamaan dengan meratakan tanah, memupuk, menggemburkan dan membersihkan tanah dari sisa-sisa akar. Selanjutnya dibuat petak-petak demplot sebanyak 4 petak dan masing-masing petak demplot berukuran $10 \mathrm{~m}$ x $1 \mathrm{~m}$ dan tinggi bedengan $50 \mathrm{~cm}$.

\section{Aplikasi Pupuk Hayati Mikoriza dan Bahan Organik}

Inokulasi MA dilakukan pada saat tanam dengan cara disebar merata membentuk satu lapisan di bawah benih sawi. Inukulum yang digunakan adalah campuran akar spora mikoriza dan medium yang sudah dibuat sebelumnya dalam bentuk tepung dengan dosis 5 ton/ ha 
dengan cara di sebar merata di atas bedeng bersama dengan pemberian pupuk kandang dengan dosis 12 ton/ha diberikan pada saat tanam.

\section{Penanaman Benih Sawi}

Benih sawi sebelum ditanam dicampu hingga rata dengan pasir untuk memudahkan penaburannya dan hasilnya bisa rata. Penanaman benih sawi dilakukan dengan cara di sebar merata dengan menggunakan tangan pada setiap bedengan bersamaan dengan pemberian pupuk hayati mikoriza dan pupuk kandang. Selanjutnya bedengan disiram dengan gembor secara hati-hati jangan sampai benih tercecer terkena percikan air.

5. Pemeliharaan Tanaman

1) Pemupukan

Pemupukan dilakukan dengan menggunakan pupuk anorganik (Urea, SP36 dan Phonska), diberikan sesuai dosis rekomendasi untuk tanaman sawi. (urea $50 \mathrm{~kg}$, phonska $100 \mathrm{~kg} / \mathrm{ha}$ ). Pupuk SP36 diberikan pada 2 hari sebelum tanam, sedangkan urea dan phonska 1/3 dosis pupuk urea dan phonska di berikan pada 10 hari setelah tanam (hst) dengan cara di dilarutkan dengan air kemudian disiram dengan merata. Adapun 2/3 dosis pupuk urea dan phonska diberikan pada 20 hari setelah tanam (hst) dengan cara dilarutkan dengan air dan disiram dengan gembor hingga rata.

2) Pengairan

Pengairan dilakukan dengan cara disiram dengan menggunakan gembor secara merata sampai mencapai kapasitas lapang yang dilakukan setiap dua minggu sekali.

3) Penyiangan dan Pengendalian Hama Penyakit dan Gulma

Penyiangan dilakukan dengan cara mencabut gulma yang ada di sekitar tanaman, penyiangan dilakukan setiap 3 hari sekali. Sedangkan untuk pengendalian hama dan penyakit dilakukan dengan pestisida organik Azadiracthin yang merupakan ekstrak daun Nimba dengan nama dagang OrgaNeem dengan konsentrasi $5 \mathrm{ml}$ per liter air dengan interval penyemprotan 3 hari sekali.

c. Evaluasi partisipatif

Untuk melihat hasil dari pengabdian pada masyarakat ini diperlukan evaluasi yang kemudian dibandingkan dengan petani pembanding, evaluasi tersebut meliputi :

1. Umur panen sawi

2. Bobot sawi per tanaman

3. Bobot brangkasan segar (kg/petak)

4. Jumlah spora per $100 \mathrm{~g}$ tanah

5. Persentase infeksi pada akar

6. Analisis ekonomi dan kelayakan usaha budidaya sawi organik

7. Kehadiran dan partisipasi peserta dalam mengadopsi teknologi yang diberikan

8. Diskusi dan pertanyaan selama penyuluhan berlangsung.

\section{HASIL DAN PEMBAHASAN}

\section{A. Partisipasi petani mengikuti penyuluhan}

Partisipasi petani dalam mengikuti penyuluhan pertanian sangat antusias, yang membuat petani menjadi bisa, yang awalnya tidak tahu menjadi tahu (Gambar 1). Gambar 1 
memperlihatkan petani terlibat aktif dalam kegiatan penyuluhan. Petani ikut serta dan berpartisipasi aktif. Ini terlihat dari pertanyaan-pertanyaan yang diajukan dalam sesi diskusi yang sangat relevan dan berhubungan dengan materi yang disampaikan pada saat penyuluhan. Ini menggambarkan petani tidaklah bodoh, dialah yang paling tahu permasalahan yang dihadapi di lapangan. Namun kelemahan dari petani, terutama yang tergolong "petani gurem" dan berpendidikan rendah dan tidak aktif dalam kelompok tani biasanya kurang partisipasinya dan lambat menyerap materi penyuluhan yang diberikan.

Mengikut sertakan petani dalam kegiatan penyuluhan dan demlot sebenarnya dimaksudkan agar petani sadar akan permasalahan dan kebutuhannya, sehingga diharapkan petani dapat mencari alternatif jalan keluar dari permasalahannya (Nasdian, 2014). Namun demikian jika dilihat kondisi riil petani di lapangan, partisipasi yang umum dilakukan adalah partisipasi parsial (Ndraha, 1982). Hal ini mungkin disebabkan oleh kondisi patani yang umumnya tergolong "petani gurem", miskin dan minim fasilitas.

Oleh sebab itu, agar kegiatan penyuluhan dan demplot budidaya sawi dapat merubah pola piker petani menjadi lebih cepat dan terarah, jika tidak ada kekuatan atau potensi dari petani itu sendiri, maka akan sulit melakukan perubahan (Setiana, 2005). Partisipasi petani dalam proses pembangunan pertanian secara umum dan kegiatan penyuluhan khususnya akan menjadi nyata apabila ada tiga faktor utama yang mendukung, yaitu (1) kemauan kuat, (2) kemampuan, dan (3) kesempatan bagi petani untuk berpartisipasi.

Melalui partisipasi petani pada kegiatan penyuluhan dan demplot budidaya sawi umur genjah dimaksudkan agar petani mendengar, melihat dan terlibat langsung dalam kegiatan pertanian, sehingga lebih fokus dan terarah, artinya program kegiatan pertanian disusun sesuai dengan yang dibutuhkan petani, sehingga dapat terlaksana secara efektif dan efisien (Adisasmita, 2006).

Namun demikian partisipasi petani dalam kegiatan pertanian akan tumbuh baik dipengaruhi oleh banyak faktor. Faktor-faktor yang mempengaruhi petani untuk berpartisipasi aktif dalam kegiatan penyuluhan yaitu usia, jenis kelamin, pendidikan, pekerjaan dan penghasilan, serta lamanya tinggal di daerah tersebut. Sedangkan faktor internal yang berhubungan secara nyata dengan partisipasi petani dalam program penyuluhan adalah pendidikan formal, pengalaman sebagai kontak tani, sifat kekosmopolitan, frekuensi komunikasi dan tingkat pendapatan. Faktor eksternal yang terkait nyata dengan partisipasi petani dalam penyuluhan dan demplot pertanian adalah intensitas kegiatan penyuluhan dan keikutsertaannya dalam kelembagaan di desa.

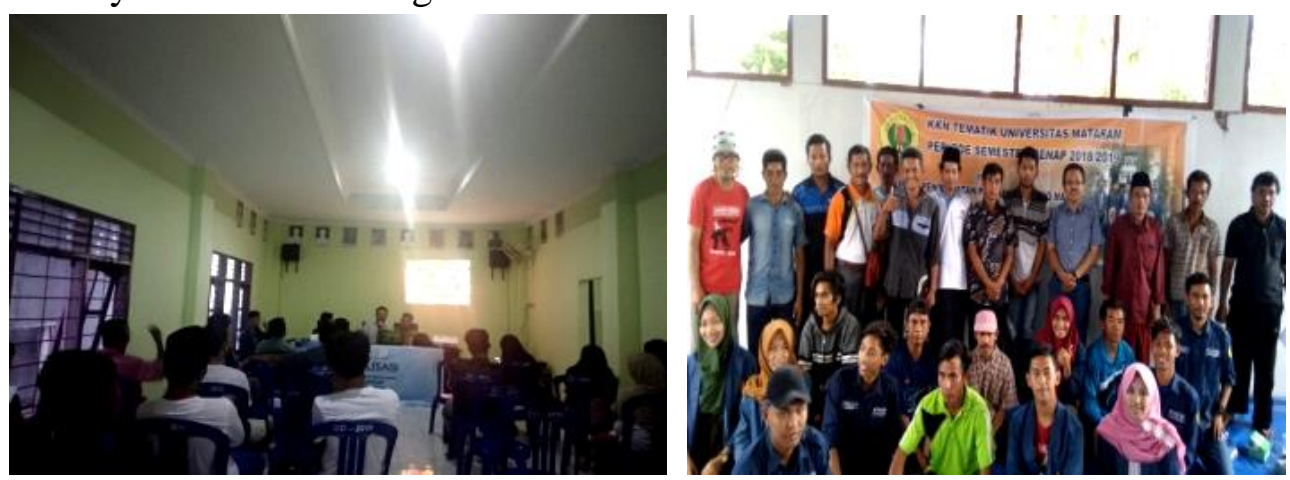

Gambar 1. Partisipasi petani pada kegiatan penyuluhan saat mengikuti penjelasan materi penyuluhan oleh tim penyuluh dari Fakultas Pertanian Unram 


\section{B. Hasil demplot sawi dengan aplikasi pupuk mikoriza dan penambahan bahan organik}

Kegiatan demplot budidaya tanaman sawi dengan aplikasi pupuk hayati mikoriza dan penambahan bahan organik, mulai dari persiapan lahan, penanaman, pertumbuhan tanaman dan panen dapat dilihat pada Gambar 2. Demplot ini dilakukan oleh Kelompok Tani dibawah bimbingan dan arahan Tim Penyuluhan dari Fakultas Pertanian Universitas Mataram tentang teknis budidaya sawi umur genjah dengan menggunakan pupuk hayati mikoriza dan penambahan bahan organik. Kegiatan demplot ini juga dibantu oleh adik-adik mahasiswa yang sedang melakukan kegiatan Kuliah Kerja Nyata Tematik, sehingga ada proses transfer teknologi baik kepada adik-adik mahasiswa maupun kepada kelompok tani dapat secara bersama-sama.
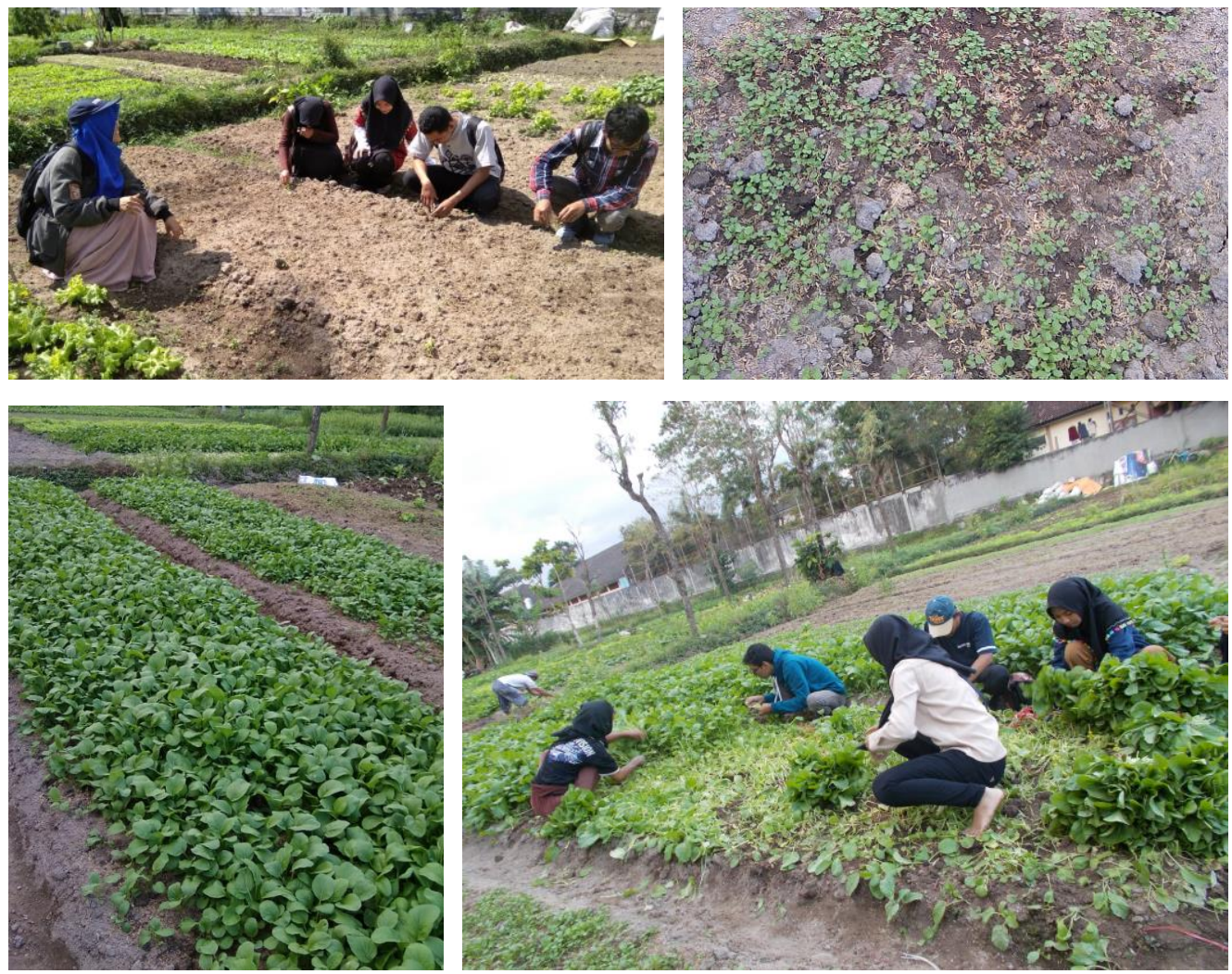

Gambar 2. Demplot budidaya sawi umur genjah dengan aplikasi pupuk hayati mikoriza dan bahan organik

Setelah sawi dipanen kemudian diikat dan ditimbang beratnya lalu dilakukan pelabelan dengan menggunakan desain dan kemasan yang menarik. Pada desain ditunjukkan kontak pearson agar memudahkan dalam pemesannya secara on line. Sawi organik ini setelah dikemas dan diberi label menjadi terlihat rapi dan menarik sehingga menarik konsumen untuk membeli. Setelah pelabelan selesai, sawi yang telah dikemas kemudian dijual di kawasan taman Udayana pada hari minggu saat car free day diberlakukan di kawasan tersebut. Begitu lapak digelar, nampak pembeli berdatangan untuk membeli sawi organik yang terlihat menarik dan menggugah konsumen untuk membelinya. Banyak komentar positif dari para pembeli yang mengingikan kontinuitas penjualan produk dan disarankan agar lebih menganeka ragamkan jenis sayurannya, misalnya selada, pitsai, sawi mangkok, brokoli dan sayuran organik lainnya. Untuk tahap awal harga jual per tiga ikat dibandrol harga Rp 5000,- 
sehingga kesannya tidak terlalu mahal dan sehat untuk dikonsumsi. Hal ini ternyata terbukti benar, lapak dibuka jam 07.30 pagi, dagangan sudah habis jam 08.30 pagi. Banyak ibu-ibu sehabis jalan-jalan dan olahraga, mau membeli setelah olahraga sudah kehabisan stok sawi organik. Nampak bahwa dengan kemasan yang menarik dan terkesan bersih dan sehat, sawi ini banyak diminati, dibandingkan dengan milik petani yang tidak dikemas dan tidak dilabel. Aktifitas penjulan di taman Udayana secara lengkap dapat dilihat pada Gambar 3.
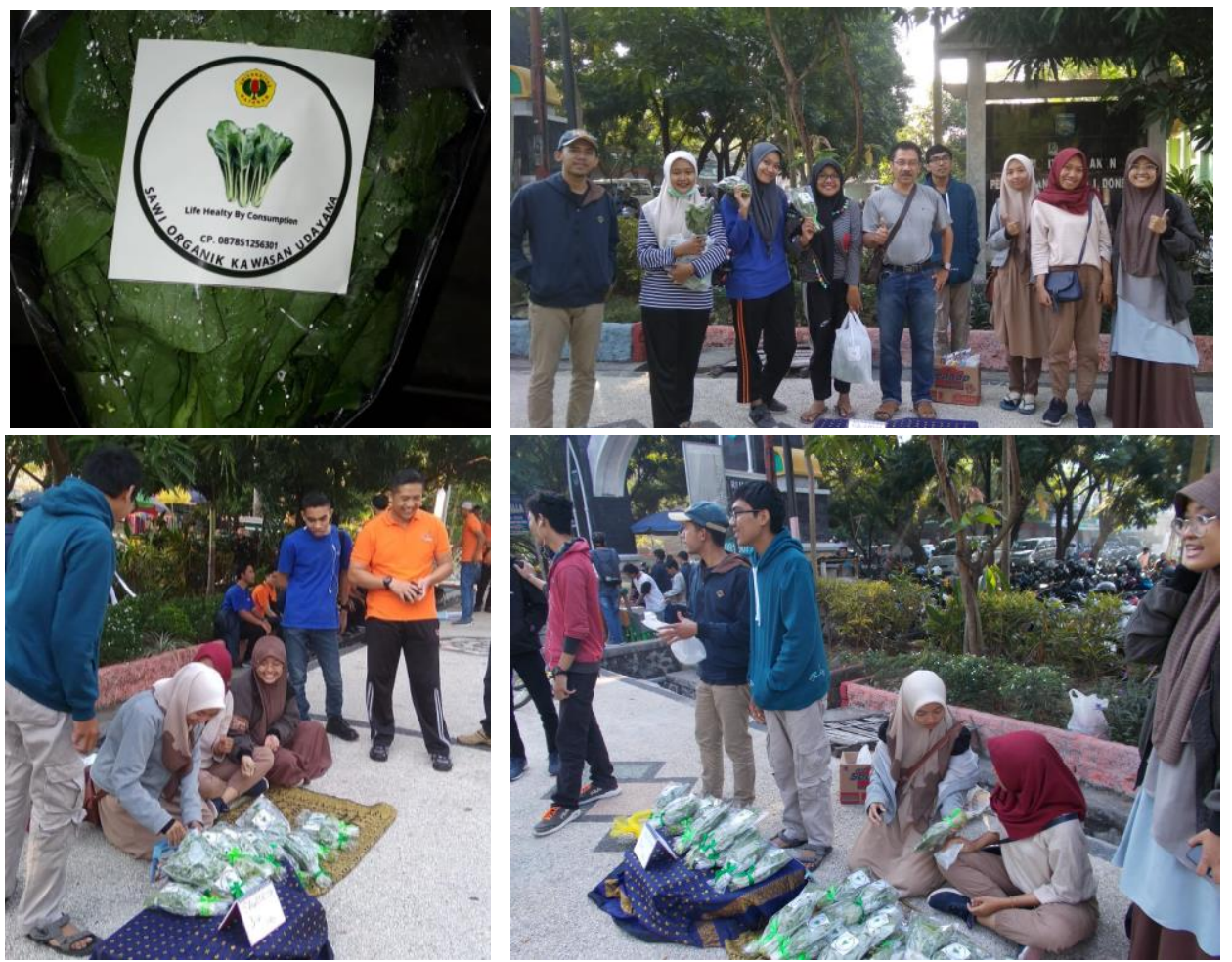

Gambar 3. Pelabelan sawi organik identitas kawasan taman Udayana dan pemasarannya di kawasan taman Udayana

Hasil pengamatan parameter berupa umur panen, bobot sawi segar per tanaman, bobot sawi segar per petak, derajat infeksi pada akar, jumlah spora per $100 \mathrm{~g}$ tanah dan nilai B/C ratio dapat dilihat pada Tabel 1. Pengamatan dilakukan pada sepuluh tanaman sampel dan ubinan untuk berat segar sawi per petak, kemudian hasil pengamatan yang diperoleh dirataratakan, sehingga hasil akhir adalah hasil rata-rata.

Tabel 1. Hasil pengamatan parameter demplot sawi organik umur genjah di kawasan taman Udayana

\begin{tabular}{lcc}
\hline Pengamatan parameter & Teknologi organik & Teknologi petani \\
\hline Umur panen sawi (hari) & 35 & 45 \\
Bobot sawi segar per tanaman $(\mathrm{g})$ & 15,25 & 7,25 \\
Bobot sawi segar per petak(kg/petak) & 15,12 & 7,15 \\
Derajat infeksi mikoriza (\%) & 67 & 31 \\
Jumlah spora mikoriza per 100 g tanah & 3760 & 1450 \\
Analisis ekonomi (B/C ratio) & 1,85 & 0,79 \\
\hline
\end{tabular}

Dari Tabel 1 terlihat bahwa dari parameter bobot sawi segar per tanaman, bobot sawi per petak, derajat infeksi dan jumlah spora hasilnya melampaui jauh dari rata-rata teknologi konvensional yang biasa dibudidayakan petani yaitu diatas 50\%. Dari Tabel 1 di atas dapat 
dilihat nilai $\mathrm{B} / \mathrm{C}$ ratio budidaya sawi umur genjah adalah 1,85 yang berarti sistem usahatani ini efisien dan layak untuk dilanjutkan. Sedangkan nilai B/C ratio usahatani milik petani masih kurang dari satu $(0,79)$ yang artinya belum efisien dan produksi masih harus ditingkatkan kembali untuk dikatakan usahatani jagung layak dilanjutkan.

Peningkatan hasil yang tinggi ini disebabkan karena peranan mikoriza yang dapat merangsang pertumbuhan tanaman dengan sangat baik terutama jika dibarengi dengan pemberian pupuk kandang, sehingga pada akhirnya memberikan sumbangan yang nyata dalam peningkatan hasil tanaman. Peranan tersebut yaitu meningkatkan daya serap air, meningkatkan kesediaan unsur hara, meningkatkan kapasitas tukar kation dan meningkatkan aktivitas mikoriza. Hasil ini sejalan dengan hasil penelitian sebelumnya yang mengemukakan efektivitas spora mikoriza indigenus mampu secara efektiv meningkatkan hasil pada tanaman bawang merah (Astiko et al, 2018). Hal yang serupa juga ditemukan pada beberapa tanaman seperti jagung, bawang merah, semangka, kedelai, cabai dan tomat menunjukkan tanaman yang diinokulasi dengan mikoriza memberikan hasil yang lebih baik daripada tanaman yang tidak diinokulasi. Astiko et al. (2013) yang memfokuskan kajiannya pada pemanfaatan pupuk organik berbasis mikoriza untuk meningkatkan hasil kedelai di lahan kering Lombok Utara juga memberikan hasil serupa, aplikasi pupuk hayati mikoriza indigenus disertai pemberian pupuk kandang mampu meningkatkan kinerja biologis mikoriza yang pada ahirnya dapat meningkatkan hasil tanaman. Hasil penelitian pada budidaya sayuran dengan system tumpang gilir di daerah irigasi Pandan Duri Desa Rensing Kecamatan Sakra Barat Lombok timur direspon positif oleh petani, sehingga petani sudah mulai berfikir tentang keuntungan yang akan diperoleh jika waktu jeda antara tanaman padi dan tembakau dimanfaatkan untuk budidaya tanaman hortikultura khususnya sayuran yang berumur pendek (Bappeda Lotim dan Faperta Unram, 2014).

Lebih lanjut dari hasil penelitian Astiko et al. (2013a), menyatakan hasil tanaman dapat ditingkatkan dengan pemupukan $\mathrm{P}$ yang cukup dengan disertai penambahan bahan organik. Kondisi takaran pemupukan yang $\mathrm{P}$ yang rendah dengan penambahan pupuk kandang akan meningkatkan hasil tanaman bawang merah karena memicu peranan mikoriza dengan meningkatnya jumlah spora di dalam tanah. Meningkatnya peranan mikoriza dalam meningkatkan hasil tanaman juga dipengaruhi oleh faktor-faktor lingkungan yang dinamis, dimana pada kondisi pemupukan $\mathrm{P}$ yang rendah dengan penambahan bahan organik akan menunjang perubahan anatomi dan fisiologi di dalam akar yang memacu peningkatan sporulasi spora dan infeksi akar.

\section{KESIMPULAN DAN SARAN}

Berdasarkan hasil kegiatan pengabdian kepada masyarakat yang telah dilakukan di Dusun Muncuk Kelurahan Rembiga Mataram, maka dapat dikemukaan beberapa simpulan sebagai berikut :

1. Penyuluhan tentang aplikasi pupuk hayati mikoriza pada tanaman sawi umur genjah berhasil meningkatkan pemahaman petani tentang pentingnya cara budidaya sawi organik.

2. Nilai B/C ratio budidaya sawi organik umur genjah adalah 1,85 yang efisien dan menguntungkan.

3. Antusiasme petani terhadap kegiatan penyuluhan dan demplot sawi organik umur genjah sangat baik dan tingkat partisipasi dari kelompok tani tinggi. 


\section{Ucapan Terima kasih}

Penulis menyampaikan ucapan terimakasih kepada Rektor dan Ketua Lembaga Penelitian dan Pengabdian Masyarakat Universitas Mataram atas pemberian dana melalui DIPA BLU Skema Program Pengabdian Pada Masyarakat Kemitraan Tahun Anggaran 2019 nomor: 2158/UN18/LPPM/2019.

\section{DAFTAR PUSTAKA}

Adisasmita R.. 2006. Membangun Desa Partisipatif. Yogyakarta [ID]: Graha Ilmu

Astiko, W., I.R. Sastrahidayat, S. Djauhari dan A. Muhibuddin. 2013. Peranan mikoriza indigenus pada pola tanam berbeda dalam meningkatkan hasil kedelai di tanah berpasir (studi kasus di lahan kering Lombok Utara. Disertasi, Pascasarjana Universitas Brawijaya. pp. 210

Astiko, W., I.R. Sastrahidayat, S. Djauhari dan A. Muhibuddin. 2013a. Soil fertility status and soybean [Glycine max (L) Merr] performence foloowing introduction of indigenous mycorrhiza combined with various nutrient sources into sandy soil. Agrivita. 35 (2): 127-137

Astiko, W. 2015. Peranan Mikoriza Indigenus pada Pola Tanam Berbeda dalam Meningkatkan Hasil Kedelai di Tanah Berpasir. Arga Puji Press. pp. 168

Astiko, W, Sudantha, I.M. Isnaini, M dan Ernawati, N.M.L. 2018. Upaya meningkatkan hasil bawang merah dengan aplikasi pupuk hayati mikoriza di Desa Seteluk Kecamatan Batulayar Lombok Barat, J. Abdi Insani. 7(2): 45-54

Bappeda Lotim dan Faperta Unram. 2014. Teknik budidaya tanaman sayuran dengan system tanam tumpang gilir di daerah irigasi Dam Pandan Duri bagian tengah Desa Rensing Kecamatan Sakra Barat Lombok Timur. Pp. 55

BPS NTB. 2015. Nusa Tenggara Barat dalam Angka (Nusa Tenggara Barat In Figure) 2015 : http://ntb.bps.go.id. Di akses : 03 November 2015.

Nasdian, F.T. 2014. Pengembangan Masyarakat. Jakarta [ID]: Yayasan Pustaka Obor Indonesia

Ndraha, T. 1982. Metodologi Penelitian Pembangunan Desa. Jakarta [ID]: PT. Bina Aksara

Satrahidayat, I. R. 2011. Rekayasa pupuk hayati mikoriza dalam meningkatkan produksi pertanian. UB Press. Malang Indonesia. pp. 226

Setiana, L. 2005. Teknik Penyuluhan dan Pemberdayaan Masyarakat. Bogor [ID]: Ghalia Indonesia. 